\title{
THE EFFECTS OF COMMUNICATIVE LANGUAGE TEACHING AND BRAIN FUNCTIONING UPON STUDENTS' SPEAKING SKILLS
}

\author{
Nugroho \\ Program Studi Pendidikan Bahasa Inggris, \\ Fakultas Bahasa dan Seni Universitas Indraprasta PGRI \\ nugroho2210@gmail.com
}

\begin{abstract}
The purpose of this study was to determine the effects of communicative language teaching and brain functioning upon student's speaking skill, to determine the influence of communicative language teaching upon student's speaking skill, and to determine the influence of brain dominance upon student's speaking skill. The research method used is experimental method. Samples were taken as many as 40 students with a simple random technique. The data was collected by distributing questionnaires directly to the sample. Data analysis using descriptive statistics such as finding the mean, median, mode, standard deviation, and inferential statistics is to look for simple and multiple correlation coefficients followed by significance test of correlation coefficient with a $t$ test. The results showed: 1) there is a significicant influence of brain dominance upon the student's speaking skill $\left.F_{\text {observed }}=5.23>F_{\text {table }}=4.49,2\right)$ there is a significant influence of communicative language teaching upon students' speaking skill $F_{\text {observed }}=7.08>F_{\text {table }}=4.49,3$ ) there is significant interaction of communicative language teaching and brain functioning upon student's speaking skill $F_{\text {observed }}=48.64>f_{\text {table }}=8.53$
\end{abstract}

Key Words: Brain Functioning, Communicative Language Teaching, Speaking Skill

\begin{abstract}
Abstrak
Tujuan dari penelitian ini adalah untuk menentukan dampak dari pengajaran bahasa komunikatif dan fungsi otak pada keterampilan berbicara siswa, untuk menentukan pengaruh pengajaran bahasa komunikatif terhadap siswa keterampilan berbicara, dan untuk menentukan pengaruh dominan otak terhadap siswa keterampilan berbicara. Metode yang digunakan adalah metode survei. Sampel diambil sebanyak 40 siswa dengan teknik acak sederhana. Pengumpulan data dilakukan dengan menyebarkan kuesioner langsung ke sampel. Analisis data menggunakan statistik deskriptif seperti menemukan mean, median, modus, standar deviasi, dan statistik inferensial adalah untuk mencari koefisien korelasi sederhana dan beberapa diikuti dengan uji signifikansi koefisien korelasi dengan uji t. Hasil penelitian menunjukkan: 1) ada pengaruh significicant otak yang dominan pada keterampilan berbicara siswa Fhitung $=5.23>$ Ftabel $=4,49,2$ ) ada pengaruh yang signifikan dari pengajaran bahasa komunikatif pada keterampilan berbicara Fhitung siswa $=7.08>$ Ftabel $=4.49,3)$ ada interaksi signifikan pengajaran bahasa yang komunikatif dan otak berfungsi pada keterampilan berbahasa Fhitung siswa $=48,64>$ Ftabel $=8.53$
\end{abstract}

Kata kunci: Fungsi Otak, Pengajaran Bahasa Komunikatif, Keterampilan Berbicara

\section{INTRODUCTION}

\section{BACKGROUND}

Speaking is one of the four macro skills necessary for effective communication in any language, particularly when speakers are not using their mother tongue. As English is universally used as a means of communication, especially in the internet world, English speaking skills should be developed along with the other 
skills so that these integrated skills will enhance communication achievement both with native speakers of English and other members of the international community. Because of the significant role of speaking in action, Bailey (2005) and Goh (2007) detailed how to enhance the development of speaking by means of syllabus design, principles of teaching, types of tasks and materials, and speaking assessment.

The most popular student-centered teaching is Communicative Language Teaching (CLT). Communicative Language Teaching emphasizes on communication and real life situations. Using Communicative Language Teaching, the teacher is supposed to create the communicative circumstances in which real life communication can be applied.

There are some techniques related to Communicative Language Teaching. Littlewoods in Richards (2001:166) distinguished two main types of techniques in Communicative Language Teaching; Functional Communication and Social Interaction. Functional communication includes tasks-based activities, following directions, and solving problems from shared clues. Social interaction includes some activities such as dialogue, role play, simulation, brainstorming, discussion, debate, storytelling and information gap.

Each technique has its own strengths and weaknesses. One technique can be appropriate for a certain class condition but it can be inappropriate for other classes' conditions. Some students enjoy getting involved while others are reluctant to participate in class. Some students can get advantages, while others cannot. This due to the fact that the students have different learning preferences.

Based on the conditions above, the teachers are demanded to choose the most appropriate teaching techniques according to students' preferences. By using the most appropriate, it hopes that the students will learn best and the successful teaching and learning target can be achieved.

In the speaking class, there are some teaching techniques that can be applied by the teachers. Role play and Information Gap are two techniques that can facilitate the communicative learning. By participating in Role Play and Information Gap activities, students can get involved in the language use communicatively.

Beside the teacher, the factors that come from the students should also be considered. Students have different interest, different ways of learning and different ways of coping with their learning problems. How the students learn the language and how they cope with their problem can influence their learning success. The students' differences should be taken into consideration in order to get better teaching process. Harmer (2007:92) stated that the task of teachers will be greatly helped if they can establish who the different students in the class are and recognize how they are different.

One of the factors that comes from the students is their learning styles. Student with different learning styles will have different learning preferences. Some styles will work better than others in different learning situation, but no one's learning style is better than another one. There are students who learn best when there is visual reinforcement such as picture, chart, etc., and there are students who learn more effectively alone while others prefer study group.

An important factor in understanding learning styles is understanding brain functioning. The students' learning styles are influenced by the participation of the brain 
hemispheres. Both sides of the brain can function but in different strategies, and one side may be dominance. Students who are left brain dominance will have different learning styles compared to the students who are right dominance. Brown (2000:54-56) stated that Intellectual, logical, analytic functions appear to be largely located in the left hemisphere, while the right hemisphere controls function related to emotional and social needs.

For some time, it was thought that one hemisphere was superior to the other in control of most activities. Crystal (2003:206) stated that today, the theory of human's brain has improved and it is recognized that each hemisphere has its own role, being more involved in the performance of some activities and less involved in others. Field (2005:15) stated that the idea of a language organ localized in the left hemisphere is challenged by evidence that the right hemisphere also contribute much more to language than that was previously thought.

Obler (1981) as explained by Brown concluded that the second language learners, particularly adult learners, might benefit from more encouragement of right-brain activity in the classroom context. Brown (2000:5657) noted that there may be greater hemisphere involvement in language processing in bilinguals who acquire second language late relative to their first language and in bilinguals who learn it informal context in order enable the most students to learn as much as they can, whether they are left brain dominance or right brain dominance, teachers need to give them every advantage, including teaching programs that enable them to start out in a relatively comfortable and stress-free way. That means that the teachers should give the students the opportunity to learn in their own styles.
Students with a certain learning style can get either advantage or disadvantage from a certain teaching technique. Therefore; the teachers should be able to choose the teaching materials suitable with the students' learning styles so that the appropriate teaching technique can be applied in the class effectively.

Teachers should be able to recognize and understand how their students learn. By understanding how the students learn, it can be helpful for the teachers to find appropriate approach or method to be used in the class so that the more effective teaching techniques and activities can be performed.

Today's world requires that the aim of teaching English should enable the students to communicate in that language. Speaking skill is one of the main priorities of most English teaching. Speaking is aimed at enabling the students to use the language properly. In order to reach that aim, teachers, certainly need to provide the appropriate techniques to promote the communication activities.

\section{DISCUSSION THEORITICAL REVIEW}

\section{The Nature of Speaking Skill}

Speaking is one of communication skills in which the speaker shares information while at the same he/she also gets information from the listener. For most people, the ability to speak a language has often been viewed as the most demanding of the other three skills. Caney (1998:13) as quoted by Kayi stated that "speaking is the process of building and sharing meaning through the use of verbal and non-verbal symbols, in a variety of context." By speaking someone can communicate his ideas or information, and share them to others at any situations and in a various contexts. 
Florez (1999:2) stated that "speaking is an interactive process of constructing meaning that involves producing and receiving and processing information". According to Bailey speaking is the productive aural/oral skill which consists of producing systematic verbal utterances to convey meaning. Moreover, Dessalles explained that speaking is the process of expressing thought, idea or feeling in the form of spoken language. Based on the definition above, speaking is the process of conveying meaning, expressing idea and feeling through verbal utterances at any situations and in various contexts.

From the above explanation we can conclude that speaking skill is one's ability to perform and share meaning through the knowledge of a language system in the form of oral activity that has been acquired by practicing or training.

\section{The Nature of Communicative Language Teaching}

Richards (2001:172) stated that Communicative Language Teaching is an approach which refers to a diverse set of principles that reflect a communicative view of language learning and that can be used to support a wide variety of classroom procedures. According to Brown (2000:266-267) CLT is best understood as an approach, not a method. He offered the following four interconnected characteristics as a definition of CLT,

1. Classroom goals are focused on all of the components of communicative competence and not restricted to grammatical or linguistic competence.

2. Language techniques are design to engage learners in pragmatic, authentic, functional use of language for meaningful purposes. Organizational language forms are not the central focus but rather aspects of language that enable the learner to accomplish those purposes.

3. Fluency and accuracy are seen as complementary principles underlying communicative techniques. At times fluency may have to take on more important than accuracy in order to keep learners meaningfully engaged in language use.

4. In the communicative classroom, students ultimately have to use the language, productively and receptively, in unrehearsed context.

5. Referring to the aforementioned descriptions, it can be concluded that Communicative Language Teaching is an approach which emphasizes communication and real life situation in order to keep learners meaningfully engaged in the language use.

Savignon (2001:16) stated that the focus of Communicative Language Teaching approach has been the elaboration and implementation of programs and methodologies that promote the development of functional language ability though students; participation in communicative events.

Nunan (1991) explained five features of Communicative Language Teaching as follows:

1. An emphasis on learning to communicate through interaction in the target language.

2. The introduction of authentic texts into the learning situation.

3. The provision of opportunities for learners to focus, not only on language but also on the learning process itself.

4. An enhancement of the learner's own personal experiences as important contributing elements to classroom learning. 
5. An attempt to link classroom language learning with language activities outside the classroom.

From the explanation above, Communicative Language Teaching can be concluded as a teaching approach that focuses on achieving the student's communicative skills in real life situation in which the teacher acts a facilitator, organizer and a guide within the classroom procedures and activities.

\section{The Nature of Brain Dominance}

Christison (2003:207) categorized learning styles into three types. The first type is cognitive styles. Cognitive styles are sub-grouped into six areas: field dependent, field independent, analytic, global, reflective and impulsive. The second type is sensory styles which are divided into two categories; perceptual and environmental learning styles. Perceptual consists of physical and sociological. The third type is personality styles. The personality styles are sub-grouped into two; tolerance and ambiguity and left and right brain dominance.

Torrance (1980) in Brown (2000:119) listed a more detailed description about left and right-brain dominance characteristics, as in the following table.

Table 1.

Brain Dominance Characteristics

\begin{tabular}{ll}
\hline Left-Brain & Right-Brain \\
Dominance & Dominance \\
\hline - Intellectual & $\bullet$ Intuitive \\
- Remembers & $\bullet$ Remembers \\
names & faces \\
- Responds to & $\bullet$ Respond to \\
verbal & demonstrated, \\
instructions and & illustrated, or \\
explanation & symbolic \\
- Experiments & instruction \\
systematically & $\bullet$ Experiment \\
and with control & randomly and \\
\hline
\end{tabular}

\begin{tabular}{|c|c|}
\hline $\begin{array}{l}\text { Makes objective } \\
\text { judgment } \\
\text { Planned and } \\
\text { structured } \\
\text { Prefers } \\
\text { established, } \\
\text { certain } \\
\text { information } \\
\text { Analytic reader } \\
\text { Reliance on } \\
\text { language in } \\
\text { thinking and } \\
\text { remembering } \\
\text { Prefers writing } \\
\text { Prefers multiple } \\
\text { choice test } \\
\text { Controls } \\
\text { feelings } \\
\text { Not good at } \\
\text { interpreting } \\
\text { body language } \\
\text { Rarely use } \\
\text { metaphors } \\
\text { Favors logical } \\
\text { problem solving }\end{array}$ & $\begin{array}{l}\text { with less } \\
\text { restraint } \\
\text { - Makes } \\
\text { subjective } \\
\text { judgment } \\
\text { - Fluid and } \\
\text { spontaneous } \\
\text { - Prefers elusive, } \\
\text { uncertain } \\
\text { information } \\
\text { - Synthesizing } \\
\text { reader } \\
\text { - Reliance on } \\
\text { image in } \\
\text { thinking and } \\
\text { remembering } \\
\text { - Prefers drawing } \\
\text { and } \\
\text { manipulating } \\
\text { objects } \\
\text { - Prefers open- } \\
\text { ended questions } \\
\text { - More free } \\
\text { feeling } \\
\text { - Good at } \\
\text { interpreting } \\
\text { body language } \\
\text { - Frequently uses } \\
\text { metaphors } \\
\text { - Favors intuitive } \\
\text { solving }\end{array}$ \\
\hline
\end{tabular}
right dominance was also stated by Christison (2003:270) in the Learning Style Taxonomy for L2 classroom. According to her, left-brain dominance learners tend to be more visual, analytical, reflective, and self-reliant. Right-brain dominance learners tend to be more auditory, global, impulsive and interactive.

From the above explanation, it can be concluded that the left and right hemispheres of our brain process information in different ways and we tend to process information using their own preferences in learning. 


\section{RESEARCH METHODOLOGY}

\section{RESEARCH METHOD AND DESIGN}

In accordance with the problem statement and objective of this study, the researcher conducted an experimental research. Doing this research, the researcher treated two different experimental classes: class VII.1 with for role play technique and VII.2 with information gap technique.

Likewise, the students in both classes were asked to answer the learning styles questionnaire which was adapted from the Hermann Brain Dominance Instrument at the end of the treatment as to find out the effect of it on the speaking skill. The research is designed by a factorial design $2 \times 2$ as follows:

Table 2.

Factorial Design $2 \times 2$

\begin{tabular}{lll}
\hline \multicolumn{1}{c}{ TT* $^{*}$} & $\begin{array}{l}\text { Role Play } \\
\text { Technique } \\
\text { (A1) }\end{array}$ & $\begin{array}{l}\text { Information } \\
\text { Gap } \\
\text { Technique } \\
\text { (A2) }\end{array}$ \\
\hline $\begin{array}{l}\text { Right-brain } \\
\text { dominance } \\
\text { (B1) }\end{array}$ & A1B1 & A2B1 \\
\hline
\end{tabular}

Left-brain

dominance $\quad$ A1B1 A2B2

(B2)

\begin{tabular}{l}
\hline Total A $\quad$ B \\
\hline TT $^{*}=$ Teaching Techniques \\
BD $^{*}=$ Brain Dominance
\end{tabular}

The Population and Sampling Method

Population is a generalization which consists of objects or subjects to ensure that the quantity and characteristics applied by researchers to study and then drawn the conclusion (Sugiyono, 2002:52).

The population of this research was all students at SMPN 138 Jakarta who took Speaking Skill as part of English Subject. The sample of this research was taken based on the multiple stage method with equal characteristics and probability. Nazir (2003:277) stated that in this sampling method, every member of selected groups have similar characteristic and probabilities.

\section{The Technique of Collecting Data}

There were two classes treated in this experiment, one was class VII.1 which was treated by using Information Gap technique and another was class VII.3 which was treated by using Role Play technique. The number of students in each class was 36 . The sample was selected from those who took final test and answered all the Learning Style Inventory Questionnaire. The composition of the sample according to the treatment can be seen in the following table:

Table 3.

The Composition of the sample

\begin{tabular}{lll}
\hline TT* & $\begin{array}{l}\text { Role Play } \\
\text { Technique } \\
\text { BD1) }\end{array}$ & $\begin{array}{l}\text { Information } \\
\text { Gap } \\
\text { Technique } \\
\text { (A2) }\end{array}$ \\
\hline $\begin{array}{l}\text { Right- } \\
\text { brain } \\
\text { dominant } \\
\text { (B1) }\end{array}$ & 12 & 11 \\
\hline $\begin{array}{l}\text { Left- } \\
\text { brain } \\
\text { dominant } \\
\text { (B2) }\end{array}$ & 8 & 9 \\
\hline Total & 20 & \\
\hline & & 20 \\
\hline
\end{tabular}

\section{Data Analysis Technique}

In testing the null hypothesis, twoway Analysis of Variance (ANOVA 2X2) technique was adopted after doing a required test which included normality and homogeneity. 


\section{Normality test}

Normality test is done by using the Lilliefors. Data that is considered normal if the price $F_{\text {observed }}<F_{\text {table }}$ tested with a significance level $\alpha=0.05$. As for linear data if $F_{\text {observed }}<F_{\text {table }}$ tested with a significance level $\alpha=0.05$.

\section{Homogeneity test}

Homogeneity of the test is designed to test the version of the normal distribution of the population, the homogeneity of the test carried out by the Bartlett test (Sudjana, 2001: 216). Deviation said homogeneous if $F_{\text {observed }}<F_{\text {table }}$, tested with a high level of $\alpha=0.05$.

The null hypotheses of this study which were tested are as follows:

$\mathrm{H}_{01}$ : The speaking skills of the students resulting from Role Play technique is the same or lower than that resulting from information gap technique.
$\mathrm{H}_{02}$ : The right-brain dominant students' speaking skills resulting from Role Play technique is the same or lower than that resulting from information gap technique.

$\mathrm{H}_{03}$ : The left-brain dominant students' speaking skills resulting from information gap technique is the same or lower than that resulting from Role Play technique.

$\mathrm{H}_{04}$ : There is no influence of interaction between communicative language teaching techniques and learning styles on the students speaking skill.

\section{Correlation Coefficient}

Inter rater test which is used is Correlation of Spearman Rank works ordinal data or ranking, and free distribution. Sugiyono(2002:228)

$$
\begin{aligned}
& \rho=1-\frac{6 \Sigma \mathrm{bi}^{2}}{\mathrm{n}\left(\mathrm{n}^{2}-1\right)} \\
& \rho=\text { Correlation Coefficient of Spearman } \\
& \text { Rank }
\end{aligned}
$$

\section{Statistical Hypothesis}

The followings are the statistical hypothesis of this research:

\begin{tabular}{|c|c|c|}
\hline $\begin{array}{ll}\mathrm{BD}^{*} & \mathrm{TT}^{*} \\
\end{array}$ & $\begin{array}{c}\text { Role Play Technique } \\
\text { (A1) }\end{array}$ & $\begin{array}{c}\text { Information Gap } \\
\text { Technique (A2) }\end{array}$ \\
\hline Right-brain dominant (B1) & \multicolumn{2}{|c|}{ Hypothesis 2} \\
\hline Left-brain dominant & Hypot & sis 3 \\
\hline Total & \multicolumn{2}{|c|}{ Hypothesis 1} \\
\hline
\end{tabular}

Based on the result of a two way analysis of variance with interaction

\begin{tabular}{|c|c|c|}
\hline $\mathrm{H}_{01}: \mu \mathrm{A}_{1}$ & $\leq$ & $\mu \mathrm{A}_{2}$ \\
\hline $\mathrm{H}_{02}: \mu \mathrm{A}_{1} \mathrm{~B}_{1}$ & $\leq$ & $\mu \mathrm{A}_{2} \mathrm{~B}_{1}$ \\
\hline $\mathrm{H}_{03}: \mu \mathrm{A}_{2} \mathrm{~B}_{2}$ & $\leq$ & $\mu \mathrm{A}_{1} \mathrm{~B}_{2}$ \\
\hline $\mathrm{H}_{04}:$ A X B & $=$ & 0 \\
\hline
\end{tabular}
(ANOVA2X2) and the Scheffe's test, the following table shows the conclusion: 
Null hypothesis is rejected at significance level of 0.05

$\begin{array}{lll}\mathrm{H}_{11}: \mu \mathrm{A}_{1} & > & \mu \mathrm{A}_{2} \\ \mathrm{H}_{12}: \mu \mathrm{A}_{1} \mathrm{~B}_{2} & > & \mu \mathrm{A}_{2} \mathrm{~B}_{1} \\ \mathrm{H}_{13}: \mu \mathrm{A}_{2} \mathrm{~B}_{2} & > & \mu \mathrm{A}_{1} \mathrm{~B}_{2} \\ \mathrm{H}_{14}: \mathrm{AXB} & \neq & 0\end{array}$

Explanation:

$H_{0} \quad=$ null hypothesis

$H_{1} \quad=$ alternative hypothesis

$\mu \mathrm{A}_{1}=$ The average score of the students' speaking skill resulting from Role Play Technique.

$\mu \mathrm{A}_{2} \quad=$ The average score of the students' speaking skill resulting from Information Gap Technique.

$\mu \mathrm{B} 1=$ The average score of the right-brain dominant students' speaking skill.

$\mu \mathrm{B} 2=$ The average score of left-brain dominant students' speaking skill

A X B $=$ The interaction between Communicative Language Teaching Techniques and Brain Functioning/Dominant.

\section{RESEARCH FINDINGS AND DISCUSSION}

The hypothesis test performed in this research uses a two way analysis of variance with interaction (ANOVA 2X2). This analysis is performed to investigate two or more variables and the interactions between them. In this research the analysis is aimed at finding the difference of teaching technique and brain dominance on the student's speaking skill.

\section{DISCUSSION}

Based on the calculation in the two tables above, it can be described the following:

1. Brain Dominance Variable

Based on the ANOVA 2X 2 test result, the value of $F_{\text {observed }}=5.23$, compared to the value of $F_{\text {table }}=4.49$, it can be seen that $F_{\text {observed }}>F_{\text {table }}$ at significant level of 0.05 . This means that there is a significant influence of brain dominance on the students speaking skill at significant level of 0.05
2. Teaching Technique Variable

From the calculation it can be seen that the score of $F_{\text {observed }}>F_{\text {table, }}$ in which $F_{\text {observed }}=7.08>F_{\text {table }}=4.49$ at significant level of 0.05 . This means that there is a significant influence of teaching technique on the student's speaking skill at significant level of 0.05 .

3. The Interaction between Brain Dominance and Teaching Techniques

As shown in the table of calculation, it can be concluded that there is a significant difference between the brain dominance and teaching technique upon the student's speaking skill. It can be shown from the result of ANOVA test which the value of $\mathrm{F}_{\text {observed }}=$ $48.64>\mathrm{F}_{\text {table }}=8.53$ at significant level of 0.01 .

The result of variance analysis shows that there is significant difference of speaking skill between both experimental groups with right and left brain dominance. In order to determine the modest influence of teaching technique on the student's speaking skill, and then there is a need to perform further analysis. 
As mentioned in the previous part, the next analysis, the Scheffe's is done to find: (1) the different effect of teaching techniques on the student's speaking skill, (2) the difference of speaking skill of the right brain dominance of students who study with Role Play technique and Information Gap technique, (3) the difference of speaking skill of the left brain dominance students who study with Information Gap technique, and (4) the influence of interaction between teaching techniques and brain dominance upon student's speaking skill.

Since the result of ANOVA $2 \mathrm{X} 2$ indicates that there is influence of interaction between the right brain dominance and the Communicative Language Teaching techniques, the test is continued by using the Scheffe's test to see the influence of teaching techniques and the brain dominance on student's speaking skill.

1. The Different Effect of Communication Teaching Techniques on the Student's Speaking Skill.

The analysis with the Scheffe's test shows that the value of $\mathrm{F}_{\text {observed }}=0.94<\mathrm{F}_{\text {table }}=2.80, \quad$ which means that there is no significant difference between the student's speaking skill resulting from Role Play and Information Gap technique at significant level of $\alpha=0.05$.

The difference is not indicated by the different average score of speaking test in which the speaking score of the students who study with Role Play technique is higher than those who study with Information Gap technique. The average score of speaking skill of students who study with Role Play technique is 77 and the average score of students who study with Information Gap technique is 74.46. It can be concluded the null hypothesis is accepted.

2. The Difference of Speaking Skill of the Right Brain Dominance Students Who Study with Role Play and Information Gap Technique

After calculating the $\mathrm{F}_{0}$ compared to $F_{\text {table, }}$ it can be seen that $\mathrm{F}_{0}=0.25<\mathrm{F}_{\text {table }}=2.80$. Based on this condition, it can be concluded that there is no significant difference of speaking skill between those who study with Role Play and Information Gap technique this difference is not indicated the difference average score of speaking skill of students who study with Role Play than those who study with Information Gap.

3. The Difference of Speaking Skill of The Left Brain Dominance Students Resulting from Role Play Technique and Information Gap Technique.

The result of Scheffe's test calculation shows that $\mathrm{F}_{0}=2.90<\mathrm{F}_{\mathrm{t}}=$ 2.80 at significant level of $\alpha=0.05$. It means that there is significant difference of speaking skill of left brain dominance students who study with Role Play and Information Gap. Based on this result, it can be concluded the $\mathrm{H}_{0}$ is accepted.

The difference of average score of the speaking skill of students resulting from Role Play technique and Information Gap technique is shown in the following figure:

4. The Influence of Interaction between Teaching Technique and Brain Dominance Upon The Student's Speaking Skill.

As stated in the result of Analysis of Variance (ANOVA) $\mathrm{F}_{0}=48.64>\mathrm{F}_{\mathrm{t}}=8.53 \mathrm{at}$ significant level of $\alpha=0.01$. It can be concluded that there is significant difference 
between interaction of brain dominance and Communicative Language Teaching upon student's speaking skill.

The score calculation shows that the right brain dominance students who study with Information Gap have higher average score than those who study with Role Play technique; the left brain dominance students who study with Role Play have higher average score than those who study with Information Gap technique. This illustration means that the null hypothesis of this research is rejected.

As discussed in the previous part, the last null hypothesis is rejected which means that there is significant influence of interaction between language teaching technique and brain dominance upon the student's speaking skill

\section{CONCLUSION}

Based on the data description of the research and after doing an analysis, so it can be concluded that:

1. There is a significant influence of brain dominance on the students speaking skill.

2. There is a significant influence of teaching technique on the student's speaking skill.

3. There is a significant difference between the brain dominance and teaching technique upon the student's speaking skill.

\section{BIBLIOGRAPHY}

Books:

Bailey, K. M. (2005). Practical Language teaching: Speaking. New York: McGraw Hill.
Brown, H. D. (2004). Language Assessment. New York: Pearson Education.

(1994). Principles of Language Learning and teaching. New Jersey: Prentice Hall regents Eaglewood

Harmer, J. (2007). The Practice of English Language Teaching. Essex England. Pearson

Richards, J.C. (1991). Interchage. New York: Cambridge University Press.

Santoso, R. (2001). Right Brain. Jakarta: PT. Gramedia

Sari, L. (2004). Assessing Speaking. Cambridge. Cambridge: University Press.

Setiawati, L. and Anggraini, F.R.R. (2011). Mudah Mengelola Data Penelitian dengan Excel. Jakarta: PT. Elex Media Komputindo

Sudjana. (2005). Metoda Statistika. Bandung: Tarsito

Sugiyono. (2002). Statistika untuk Penelitian. Bandung: $\mathrm{CV}$. AlfaBeta

\section{Internet:}

Differences between left and right hemisphere from http://capone.mtsu.edu/studskl/h d/hemis.html

Emily Holbrook. Left Brain Vs. Right Brain Function in Learning from http://www.funderstanding.com/ brain/left-brain-vs-right-brainteaching-techniques/

Kelly McLendon. 2011. Left Brain Learning. From http://www.funderstanding.com/ brain/left-brain-learning/ 
Sarah Lipoff. 2011. Right Brain Dominant Learner. From http://sarahlipoff.com/2012/04/1 7/right-brain-dominant-kids/

Maria A. Kodotchigova. 2011. Role play in Teaching Culture: Six Quick Steps for Classroom Implementation. Rusia. Tomsk State University. From
http://iteslj.org/Techniques/Kod otchigova-RolePlay.html

Patricia K. Tompkins. Role Playing/Simulation. The Internet TESL Journal, Vol. 8, August 1998.

From http://iteslj.org/Techniques/Tom pkins-RolePlaying.html 